\title{
SPARFLOXACIN - A POTENTIAL CONTAMINANT OF ORGANICALLY GROWN PLANTS?
}

\author{
ZIÓŁKOWSKA, A. - PIOTROWICZ-CIEŚLAK, A. I. \\ Department of Plant Physiology, Genetics and Biotechnology, Faculty of Biology and \\ Biotechnology, University of Warmia and Mazury in Olsztyn, Oczapowskiego 1A, 10-718 \\ Olsztyn, Poland \\ *Corresponding author: \\ e-mail: acieslak@uwm.edu.pl \\ (Received $16^{\text {th }}$ Mar 2016; accepted $16^{\text {th }}$ Jun 2016)
}

\begin{abstract}
Pharmaceuticals in water and soil ecosystems increasingly become a problem for environmental protection and agriculture. They may be transferred to soil and plants even in organic production systems as they often occur in manure. This paper presents assessment of sparfloxacin effect on protein profile and activity of guaiacol peroxidase in pea roots. The obtained results show that sparfloxacin modifies pea root proteome. In proteomic profiles of roots from seedlings grown at the highest sparfloxacin concentration $\left(800 \mathrm{mg} \mathrm{kg}^{-1}\right)$ there were 41 proteins more than in protein separations of roots of control seedlings, in which 176 proteins were identified. A higher number of proteins, compared to control roots $(21$ more), were also obtained on separations of root proteins from plants grown in substrate „contaminated” with $40 \mathrm{mg} \mathrm{kg}^{-1}$ sparfloxacin. With increasing sparfloxacin concentration the expression of root proteins involved in cell bioenergetics decreased, while isoflavone reductase, responsible for free radicle scavenging, became up-regulated. Moreover, the presence of sparfloxacin in soil resulted in increased activity of guaiacol peroxidase. The sparfloxacin content in roots was directly proportional to the level of this pharmaceutical in soil. At the highest concentration of sparfloxacin in soil $\left(800 \mathrm{mg} \mathrm{kg}^{-1}\right)$ the level of this compound in roots reached $247 \mathrm{\mu g} \mathrm{g}^{-1}$ fresh weight. Soluble carbohydrate contents in pea tissues correlated with seedling growth (root and stem elongation), which decreased parallel to increasing concentrations of soil sparfloxacin.
\end{abstract}

Keywords: 2D electrophoresis, drug uptake, pea, protein profile, antibiotics

Abbreviations: Fluoroquinolons - FQ; Guaiacol peroxidase - POX; Reactive oxygen species - ROS; Sparfloxacin - SPX

\section{Introduction}

Common use of antibiotics in human and veterinary medicine results in their increased presence in water and soil (Sukul and Spiteller, 2007). In 1999 total use of antibiotics in European Union and Switzerland amounted to 13288 tons, of which 8637 tons were used in human medicine (65\%), 3854 tons in veterinary medicine $(29 \%)$ and 797 tons were applied as growth stimulators (6\%). However, in 2006 in France only, 1300 tons of antibiotics were used (Awad et al., 2014). It is estimated that global use of antibiotics in recent years amounted to, on average, $100-200$ thousand tons/year (Chen et al., 2012; Liu et al., 2009). During medication and after its completion, most of the applied antibiotics $(30-90 \%)$ are released to the environment, in an unmodified form or transformed to active metabolites (Liu et al., 2009; Chen et al., 2012; Pinheiro et al., 2013). For farmaceuticals the main route of entry to soil is through animal waste, used as organic fertilizers. Fluoroquinolons (FQ) are a group of antibiotics characterised by slow degradation in the environment, related to their strong adsorption to organic matter. Decay time of antibiotics and their active metabolites in manure and soil 
depends on both environmental conditions and chemical properties of the antibiotic (Seo et al., 2010). FQs are chemotherapeutics commonly used for treatment of bacterial infections (Jia et al., 2012), which results in their presence in environment at rather high levels (Khetan and Collins, 2007). FQs contents in wastewater amount to $120 \mu \mathrm{g} \mathrm{dm}^{3}$, while in groundwater and surface water it occurred at $1.3 \mu \mathrm{g} \mathrm{L}^{-1}$, and it was even detected in drinking water (Jia et al., 2012; Wammer et al., 2013).

In municipal wastewater among FQs the highest concentrations are reached by

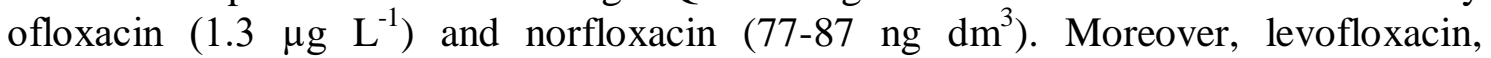
pipemidic acid, enrofloxacin and sparfloxacin were also detected (Jia et al., 2012). However, by far the highest concentrations of antibiotics were found in manure, in which they were mainly represented by tetracyclines. According to Martínez-Carballo et al. (2007) chlorotetracycline, oxytetracycline and tetracycline concentrations in manure were $46 \mathrm{mg} \mathrm{kg}^{-1}, 29 \mathrm{mg} \mathrm{kg}^{-1}$ and $23 \mathrm{mg} \mathrm{kg}^{-1}$, respectively. High concentrations of tetracyclines were found in soils of Turkey and Spain, amounting to $0.5 \mathrm{mg} \mathrm{kg}^{-1}$ and 0.2 $\mathrm{mg} \mathrm{kg}^{-1}$, respectively (Andreu et al., 2009; Karci and Balcioglu, 2009). In soils fertilised with manure the tetracycline content may even reach $7 \mathrm{mg} \mathrm{kg}^{-1}$ (Zhang et al., 2008).

FQs are taken up and accumulated in plants and their levels in plants depend on drug concentration, time of exposure and properties of the plant (Lillenberg et al., 2010; Ziółkowska et al., 2015). The mechanism of antibiotics action on plants is still unknown. Antibiotic concentrations in plants are not documented. It is not clear if antibiotic accumulation may modify plant metabolism and affect plant quality. There have been very few reports assessing antibiotic contents in plants, in contrast to drug levels in animals.

The purpose of this work was to determine the level of sparfloxacin in pea and study the effect of this drug on selected physiological-biochemical parameters of pea (peroxidase activity, protein content and 2D electrophoretic profile, as well as soluble carbohydrate contents).

\section{Materials and methods}

\section{Germination and growth}

Seeds of pea (Pisum sativum L.) cv. Cysterski were germinated for seven days in Phytotoxkit plates (MicroBio Test, Inc., Belgium). Germination was carried out under controlled climatic conditions with temperature set at $25^{\circ} \mathrm{C}$ and $90 \%$ relative humidity $(\mathrm{RH})$, under photoperiod conditions (16/8 day/night, light intensity $3.4 \mathrm{klx}$ ). Ninety millilitres of soil (sand:vermiculite:peat, 1:0.3:1, v/v/v) were placed in each plastic microbiotest plate. The soil was covered with Whatman No. 1 filter paper and watered with $27 \mathrm{ml}$ distilled water supplemented with sparfloxacin (5-Amino-1-cyclohexyl-7(cis-3,5-dimethylpiperazino)-6,8-difluoro-1,4-dihydro-4-oxo-3-quinolinecarboxylic acid; Sigma-Aldrich) at final concentrations of $0.08 ; 0.4 ; 0.8 ; 4 ; 8 ; 40 ; 80 ; 200 ; 400$; $800 \mathrm{mg} \mathrm{kg}^{-1}$ of soil. The control plants were watered with pure distilled water. The root length was estimated after seven days of germination using Image Tool for Windows. Fresh weight of seedlings was determined according to standard seed testing recommendations ISTA (2011). The experiment was carried out with four replicates, each containing 40 seedlings. 


\section{Sparfloxacin content in roots}

The content of sparfloxacin in 7-days old roots was determined. Plant sap was squeezed from fresh plant material with mortar and pestle. Roots $(500 \mathrm{mg})$ of were homogenized with $1 \mathrm{ml}$ of methanol and centrifuged for 10 minutes at $13200 \mathrm{~g}$. The obtained supernatant was transferred onto nylon filters (mesh size 0.22) (Sigma). For all extractions SPE cartridges Chromabond®Easy, $3 \mathrm{ml} / 200 \mathrm{mg}$, Macherey-Nagel, Dtiren, Germany were used. SPE cartridges were rinsed with methanol and after loading with plant saps were eluted with $250 \mu \mathrm{l}$ methanol. Tetracycline content in seedlings was analysed by HPLC according to Pailler et al. (2009) with small modifications. Briefly, the chromatographic system consisted of a Water Aliance 2695 HPLC system (Waters Corp.) with a binary high-pressure gradient pump, an automatic injector and a column oven. The chromatographic column was an Atlantis T3 column $(150 \times 3.0 \mathrm{~mm}, 3 \mu \mathrm{m})$ (Waters Corp.) at $40^{\circ}$ C. The MS-MS analyser consisted of Quattro micro® API MS (Waters Corp.) using electrospray in the positive mode (ESI+). $\mathrm{N}_{2}$ was used as nebuliser, drying, curtain and collision gas. A chromatographic gradient was applied for the separation of the analytes depending on the ionization mode employed, with a total chromatographic run of 18 min. Gradient elution was carried out with aqueous $0.1 \%$ formic acid: $0.1 \%$ formic acid in acetonitrile at a flow rate of $45 \mathrm{ml} \mathrm{min}{ }^{-1}$. Validation of the method included the assessment of selectivity, linearity ( 1 to $\left.11 \mu \mathrm{g} \mathrm{ml}^{-1}\right)$, limits of detection $\left(8 \mathrm{ng} \mathrm{ml}^{-1}\right)$ and quantification $\left(26 \mathrm{ng} \mathrm{ml}^{-1}\right)$. Chromatographic system and data collection were controlled with a MassLynx 4.1. chromatographic software interfaced to a personal computer.

\section{Activity of guaiacol peroxidase}

The activity of guaiacol peroxidase in the root tissues of seven day old pea was measured. Pea roots $(500 \mathrm{mg})$ were homogenized $(30 \mathrm{~min})$ in a porcelain mortar at $4^{\circ} \mathrm{C}$ in 5 $\mathrm{ml}$ of isolation buffer (0.1 M Tris- $\mathrm{HCl}$ (Sigma), $8.75 \%$ polyvinylpyrrolidone (Sigma), $0.1 \mathrm{M}$ $\mathrm{KCl}$ (PPH Stanlab), 0.28\% Triton X-100 (Sigma)). The supernatant was passed through a nylon filter(mesh diameter 0.45). The extract was centrifuged for 30 minutes at $4000 \mathrm{~g}$ at $4^{\circ} \mathrm{C}$. Next, the amount of isolated protein was determined by Lowry et al. (1951).

Guaiacol peroxidase activity was determined spectrophotometrically (CECLI, CE2021 2000 series). $50 \mu \mathrm{l}$ of the plant extract and $20 \mu \mathrm{l}$ of $0.06 \% \mathrm{H}_{2} \mathrm{O}_{2}$ (Chempur) were added to 2 $\mathrm{ml}$ of a reaction mixture $\left(0.1 \mathrm{M} \mathrm{KH}_{2} \mathrm{PO}_{4}\right.$ (Chempur), $100 \mu 11 \%$ guaiacol (Sigma)). The growth rate of absorbance was measured at $\lambda=470 \mathrm{~nm}$ wavelength at room temperature. One unit $(\mathrm{U})$ corresponded to oxidation of $1 \mu \mathrm{M} \mathrm{H}_{2} \mathrm{O}_{2}$ during one minute.

\section{Soluble carbohydrate contents}

Soluble carbohydrate contents in roots were analysed by gas chromatography according to Piotrowicz-Cieślak et al. (2007). Roots (500 mg fresh mass) were homogenised in ethanol:water 1:1 (v/v) containing $100 \mu \mathrm{g}$ xylitol as internal standard. The homogenate and the wash were combined in a $1.5 \mathrm{ml}$ microfuge tube, heated at $75^{\circ} \mathrm{C}$ for $30 \mathrm{~min}$ and centrifuged at $13200 \mathrm{~g}$ for $10 \mathrm{~min}$. The supernatant was passed through a $10000 \mathrm{MW}$ cut-off filter (Lida, Kenosha, WI, USA). Aliquots of $0.3 \mathrm{ml}$ filtrate were transferred to silylation vials and evaporated to dryness. Dry residues were derived with $200 \mu \mathrm{l}$ of silylation mixture (trimethylsilylimidazole : pyridine, 1:1, v/v) in silylation vials (Thermo Scientific) at $80^{\circ} \mathrm{C}$ for $45 \mathrm{~min}$, and then cooled at room temperature. One $\mu 1$ of carbohydrate extract was injected into a split-mode injector of a 
Thermo Scientific gas chromatograph equipped with flame ionisation detector. Soluble carbohydrates were analysed on a DB-1 capillary column (15 m length, $0.25 \mathrm{~mm}$ ID, $0.25 \mu \mathrm{m}$ film thickness, J\&W Scientific). Soluble carbohydrates were identified with internal standards, and their concentrations were calculated from the ratios of peak area, for each analysed carbohydrate, to the peak area of respective internal standard. Quantities of soluble carbohydrates were expressed as mean \pm standard deviation (SD) for 3-5 replications of each treatment.

\section{Two-dimensional gel electrophoresis}

Proteins were isolated from roots growing in the presence of water, or sparfloxacin at medium and the highest dose (0,40 and $800 \mathrm{mg}$ of the drug $/ \mathrm{kg}$ of soil). The roots frozen in liquid nitrogen $(2 \mathrm{~g})$ were homogenized in a porcelain mortar in an extraction buffer (500 mM TRIS with pH 8 (Sigma), $50 \mathrm{mM}$ EDTA (Sigma), $700 \mathrm{mM}$ of sucrose (Sigma), $100 \mathrm{mM} \mathrm{KCl}$ (PPH Stanlab), 0.07\% 2-mercaptoethanol (Sigma)). A $2.5 \mathrm{ml}$ dose of phenol was added to the extract and the mixture was vortexed for 10 minutes. The extract was centrifuged at $4{ }^{\circ} \mathrm{C}$ for 10 minutes at $5500 \mathrm{~g}$. After centrifuging, a phenol phase was collected and $1.8 \mathrm{ml}$ of the extraction buffer was then added. Following 3minute mixing, the samples were centrifuged for 20 minutes at $3200 \mathrm{~g}$. The phenol phase was transferred to a new tube and mixed with a four-fold volume of $100 \mathrm{mM}$ ammonium sulphate (Sigma) dissolved in cold methanol (Chempur). The mixture was incubated for 12 hours at $-20^{\circ} \mathrm{C}$. After 12 hours, precipitated proteins were centrifuged at $4^{\circ} \mathrm{C} / 3200 \mathrm{~g} / 15$ minutes and the obtained pellet was washed two times in cold acetone (Chempur) centrifuging it each time at $4{ }^{\circ} \mathrm{C} / 5500 \mathrm{~g}$ for 5 minutes. The pellet was dried at room temperature.

The dried pellet was dissolved in $9 \mathrm{M}$ urea (POCH), 20g/dm ${ }^{3}$ CHAPS (Sigma), 0.3\% DTT (Sigma) and incubated for one hour at room temperature. Next, the samples were sonicated in an ultrasonic ice bath for 15 seconds and they were then centrifuged at $14000 \mathrm{~g} / 5$ minutes. The procedure was repeated three times. The prepared solution of proteins was used in further analyses.

IPG, 7 cm, pH 4-7 strips (ReadyStrip ${ }^{\mathrm{TM}}$, Bio-Rad) were actively rehydrated for 12 hours in a rehydration buffer (Bio-Rad) with $70 \mu \mathrm{g}$ of isolated protein. Isoelectrofocusing was performed under the following conditions: $250 \mathrm{~V} / 15 \mathrm{~min}, 4000$ $\mathrm{V} / 2 \mathrm{~h} 30 \mathrm{~min}$, and then with rapidly increasing voltage up to $20,000 \mathrm{~V}$.

After isoelectric focusing, the strips were equilibrated in a buffer containing $6 \mathrm{M}$ urea, 2\% SDS, 0.375 M Tris - HCl with pH 8.8, 20\% glycerol, $130 \mathrm{mM}$ DTT (Bio-Rad) for 10 minutes and then in a buffer containing $6 \mathrm{M}$ urea, 2\% SDS, $0.375 \mathrm{M}$ Tris - $\mathrm{HCl}$ with $\mathrm{pH}=8.8,20 \%$ glycerol, $135 \mathrm{mM}$ jodoacetamid (Bio-Rad) for another 10 minutes.

In the second stage of electrophoresis, the separation of proteins was performed with $10 \%$ polyacrylamide gels $(10.0 \mathrm{~cm} \times 7.0 \mathrm{~cm})$ in a Mini-PROTEAN Tetra System apparatus for electrophoresis (Bio-Rad). Electrophoresis was run for 60 minutes at a constant voltage of $200 \mathrm{~V}$. Gels were stained in a $0.1 \%$ Commassie Brillant Blue G-250 solution (Sigma) overnight and then visualization with a Gel Doc EZ Imager (Bio-Rad) and an analysis with PDQuest (Bio-Rad) were performed.

\section{MALDI TOF/TOF analysis}

Protein spots were excised out of the gels with a scalpel, placed in test tubes, washed and destained. Proteins were dehydrated in a vacuum centrifuge and subsequently 
digested overnight in a solution of $15 \mathrm{ng}^{-1} \mathrm{l}^{-1}$ trypsin (Promega) in $25 \mathrm{mM}$ ammonium bicarbonate (Sigma). Incubation was conducted at $37^{\circ} \mathrm{C}$. The sample was sonicated for 5 minutes and dehydrated in a vacuum centrifuge and $1 \mu l$ of a previously prepared solution of $\alpha$-cyano-4-hydroxy-cinnamic acid (Sigma) was then added and dissolved in $50 \%$ acetonitrile (SIGMA) with $0.1 \%$ trifluoroacetic acid (Sigma). The entire sample was then applied onto a steel MALDI plate. Mass spectra of the peptides were taken with a MALDI TOF/TOF Autoflex III SmartBeam mass spectrometer (BruckerDaltonics). The PMF search was conducted in the NCBI database. The statistical probability of the PMF was calculated in the MASCOT database. Results exceeding 72 were taken into account $(\mathrm{p}<0.05)$.

\section{Statistical analysis}

The experiment was conducted in four replicates. The results were statistically evaluated using analysis of variance (F test) for two factor experiments (split-plot). The mean values of the plots were compared using q SNK test (Student-Newman-Keuls).

\section{Result}

\section{Germination and growth}

The effect of sparfloxacin (SPX) on elongation of roots of garden pea, cv. Cysterski, was studied after seven days of plant culture on control substrate or substrate supplemented with SPX $\left(0.08 ; 0.4 ; 0.8 ; 4 ; 8 ; 40 ; 80 ; 200 ; 400 ; 800 \mathrm{mg} \mathrm{kg}^{-1}\right.$ of soil $)$. The longest roots were found in control seedlings and measured $84 \mathrm{~mm}$. With increasing drug concentration in soil the length of roots decreased (Fig. 1A). In seedlings grown on soil contaminated with SPX at $40 \mathrm{mg} \mathrm{kg}^{-1}$ the rate of root growth decreased by $27 \%$ compared to control roots. Seedlings grown on soil with the highest SPX concentration (800 mg kg$~^{-1}$ of soil) had the shortest roots. The rate of root growth in these seedlings was lower by $54 \%$ compared to control roots (Fig. 1A). The length of pea seedlings stems also decreased with increasing antibiotic concentration (Fig. 1A). The longest stems (35 mm long) were found in control seedlings and those grown at the lowest SPX concentrations $\left(0.08,0.4,0.8,4,8 \mathrm{mg} \mathrm{kg}^{-1}\right)$. A slight decrease in stem length (by 6 and 14\%) was found in seedlings grown on soil with SPX at 40 and $80 \mathrm{mg} \mathrm{kg}^{-1}$, respectively. Seedlings growing in soil contaminated with SPX at 400 and $800 \mathrm{mg} \mathrm{kg}^{-1}$ had the shortest stems. Stem growth inhibition was 32\%, 37\% and $46 \%$ for plants grown with SPX at 200, 400, $800 \mathrm{mg} \mathrm{kg}^{-1}$, respectively (Fig. 1A).

Seedling fresh weight was also analysed, as well as their dry weight. With increasing concentration of SPX the seedling fresh weight decreased (Fig. 1B). Dry weight was lowest in control seedlings $(24 \%)$ and in seedlings grown at the highest SPX concentrations in soil (400 and $800 \mathrm{mg} \mathrm{kg}^{-1}$ ) it was highest (30 and 32\%, respectively).

\section{Sparfloxacin content in roots}

In 7-days old pea seedlings, grown in soil contaminated with increasing SPX levels, the concentrations of the content of this antibiotic in roots was 0.015 to $248 \mathrm{ng} \mathrm{g}^{-1}$ fresh weight and increased parallel to incremental doses of SPX in soil (Fig. 1C). In seedlings grown at SPX soil concentration of $40 \mathrm{mg} \mathrm{g}^{-1}$ the root content of SPX was 15 times higher than in seedlings affected by SPX at $800 \mathrm{mg} \mathrm{g}^{-1}$. 


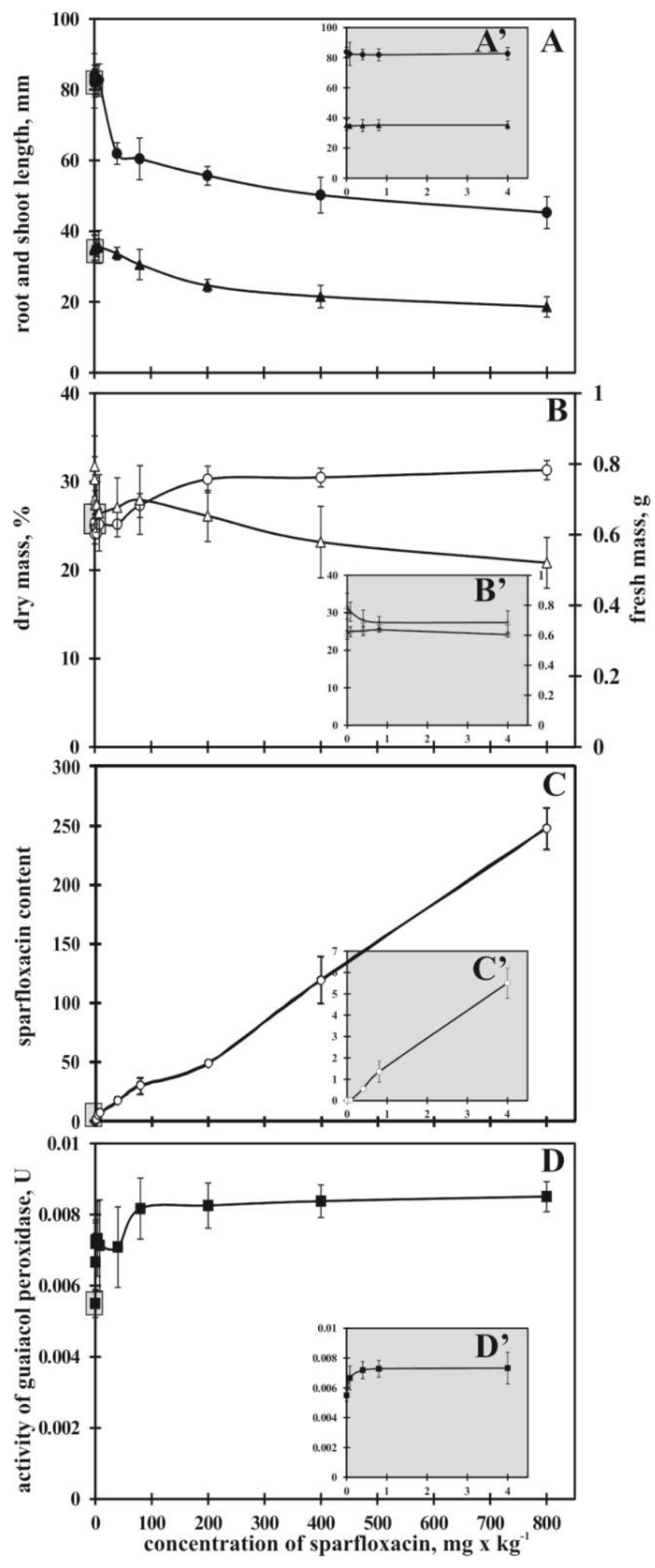

Figure 1. Panel $A-\operatorname{root}(\bullet, m m)$ and shoot $(\mathbf{\Lambda}, m m)$ length; Panel $B-d r y(\Delta, \%)$ and fresh mass $(o, m g)$; panel $C$ - sparfloxacin content $\left(o, n g \cdot g^{-1}\right.$ fresh weight); panel D-activity of guaiacol peroxidase (-, U one unit of activity equals oxidation $1 \mu \mathrm{M} \mathrm{H}_{2} \mathrm{O}_{2}$ per 1 minute) in Pisum sativum after seven days on soil supplemented with different sparfloxacin concentrations

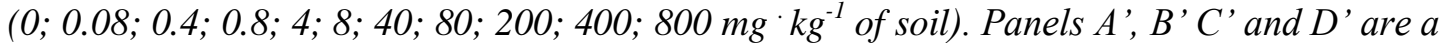
large image a gray square in the main panel $\left(0,1,2,3,4\right.$ i.e. $0,0.08,0.4,0.8,4 \mathrm{mg}^{\cdot} \mathrm{kg}^{-1}$ of soil). Data points represent the means $\pm S D$ for nine replicate samples 


\section{Activity of guaiacol peroxidase}

Guaiacol peroxidase (POX) activity in pea roots increased parallel to increasing antibiotic concentrations (Fig. 1C). The lowest POX activity was observed in roots of control seedlings and the highest in those grown at the highest dose of SPX $800 \mathrm{mg} \mathrm{kg}^{-1}$ ). At low antibiotic doses $\left(0.08,0.4\right.$ and $\left.0.8 \mathrm{mg} \mathrm{kg}^{-1}\right)$ the POX activity was by 22, 29 and $33 \%$ higher than in control seedlings. In seedlings subjected to soil SPX at 200, 400 and $800 \mathrm{mg} \mathrm{kg}^{-1}$ POX activity was higher by 49,53 and $55 \%$, compared to control seedlings, respectively.

\section{Soluble carbohydrate contents}

Soluble carbohydrates were studied in roots of pea seedlings grown for seven days in soil contaminated with SPX. Both in roots of control plants and plants affected by SPX contaminant the following sugars could be identified: fructose, glucose, myo-inositol and sucrose (Fig. 2). The highest contents of soluble sugars were found in roots of control seedlings and they amounted to $0.69,3.14,5.27,3.07 \mathrm{mg} \mathrm{g}^{-1}$ dry mass for fructose, glucose, myo-inositol and sucrose, respectively. On the other hand, it was found that with increasing SPX concentrations the contents of soluble sugars decreased (Fig. 2). Sucrose content decreased by 4 and $6 \%$ was found in roots of seedlings grown in soil containing SPX at the two lowest concentrations ( 0.08 and $0.4 \mathrm{mg} \mathrm{kg}^{-1}$, respectively) whereas SPX at $8 \mathrm{mg} \mathrm{kg}^{-1}$ decreased sucrose content by $20 \%$, compared to control roots. The lowest sucrose content $3.57,3.56$ and $3.71 \mathrm{mg} \mathrm{g}^{-1}$ dry weight was found in roots of seedlings grown in soil supplemented with SPX at the level of 200, 400 and $800 \mathrm{mg} \mathrm{kg}^{-1}$, respectively.

\section{Two-dimensional gel electrophoresis}

Protein profiles of garden pea roots were analysed using two dimensional electrophoresis (2D-PAGE). Roots of seedlings grown in control soil and at the medium and the highest SPX concentrations (40 and $800 \mathrm{mg} \mathrm{kg}^{-1}$ ) were studied. The obtained gel images were compared with one another using PDQuest ${ }^{\mathrm{TM}}$ Basic software (Fig. 3). The protein map obtained for control roots contained 176 spots (Fig. 2A), whereas for roots of seedlings growing at SPX levels 40 and $800 \mathrm{mg} \mathrm{kg}^{-1} 197$ and 217 proteins (spots) were observed, respectively (Fig. $2 B$ and $C$ ). Of all spots obtained for pea root proteins 92 spots were common for all protein maps. Twelve proteins specific for roots of SPX treated pea plants (at 40 and $800 \mathrm{mg} \mathrm{kg}^{-1}$ ) were identified based on these maps (Table 1). In roots of plants grown at SPX level $800 \mathrm{mg} \mathrm{kg}^{-1}$ there were 8 identified upregulated proteins (Fig. 4). Two dimensional maps of control root proteins revealed that 6 SPX-specific proteins, out of all 12 identified, were expressed at the highest level (Fig. 4). Increased presence of proteins involved in plant protection from stress factors or xenobiotics was observed in roots of SPX treated plants. Moreover, the amounts of proteins involved in bioenergetic metabolism (as judged by spot intensity) decreased. 


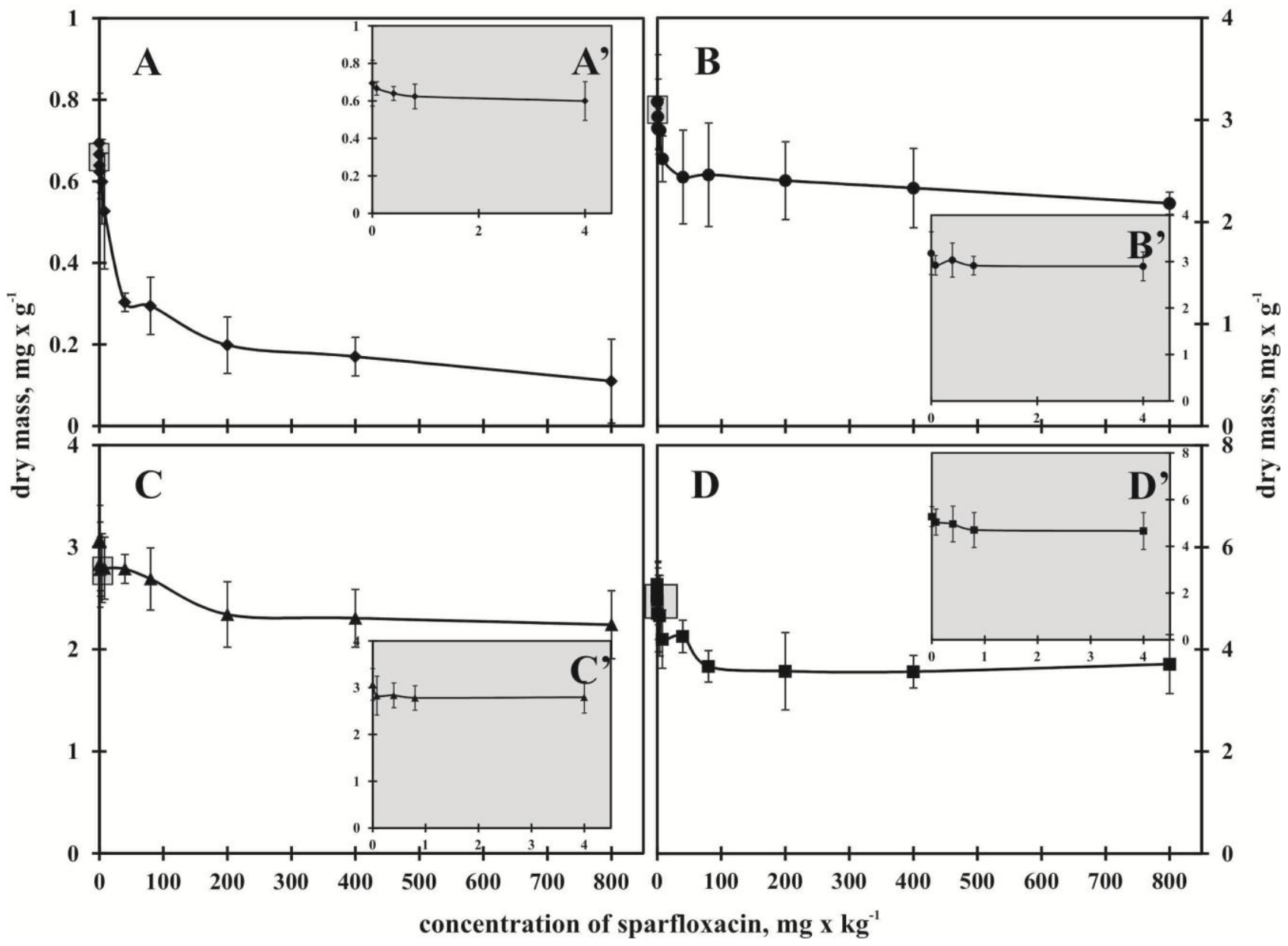

Figure 2. Panel A -fructose (,$\left.m g \cdot g^{-1}\right)$, Panel B-glucose $\left(\bullet, m g \cdot g^{-1}\right)$ panel C-myo-inositol $\left(\mathbf{\Lambda}, m g \cdot g^{-1}\right) ;$ panel D-sucrose $\left(\mathbf{\bullet}, m g \cdot g^{-1}\right)$ in Pisum sativum after seven days on soil supplemented with different sparfloxacin concentrations $\left(0 ; 0.08 ; 0.4 ; 0.8 ; 4 ; 8 ; 40 ; 80 ; 200 ; 400 ; 800 \mathrm{mg}^{\circ} \mathrm{kg}^{-1} \mathrm{of}\right.$ soil). Panels $A^{\prime}, B^{\prime} C^{\prime}$ and $D^{\prime}$ 'are a large image a gray square in the main panel $\left(0,1,2,3,4\right.$ i.e. 0, 0.08, 0.4, 0.8, $4 \mathrm{mg}^{\cdot} \mathrm{kg}^{-1}$ of soil). Data points represent the means $\pm S D$ for nine replicate samples 


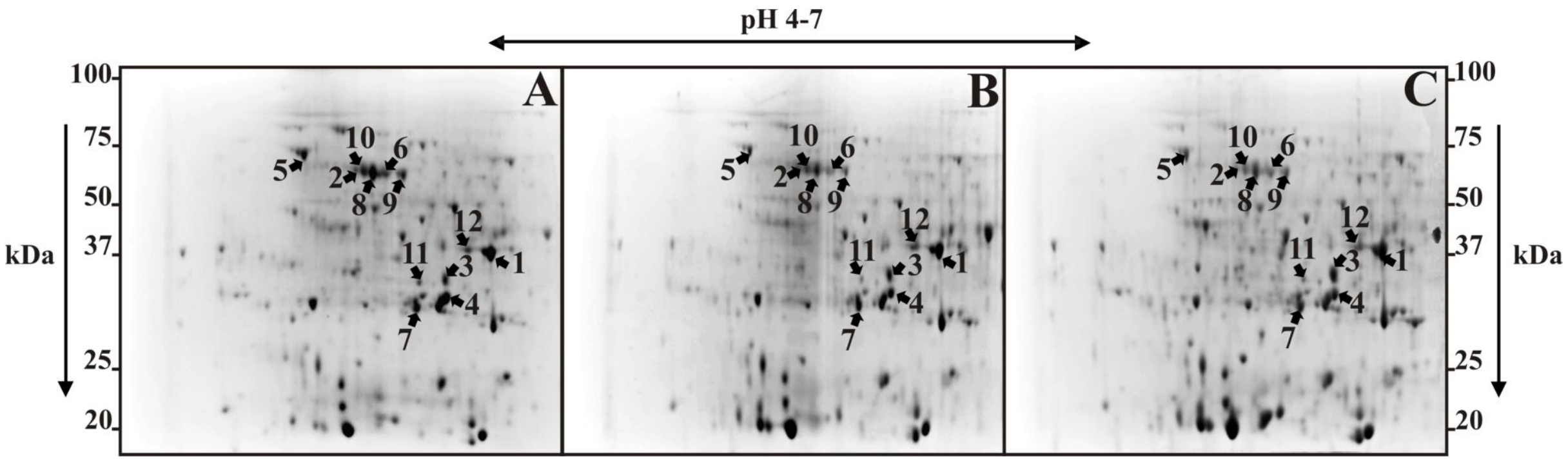

Figure 3. $2 D$ Electrophoresis of proteins of root pea (Pisum sativum L.) without (A) and with the sparfloxacin at the concentration of $40 \mathrm{mg} \cdot \mathrm{kg}^{-1}$ of soil (B), $800 \mathrm{mg}^{\cdot} \mathrm{kg}^{-1}$ of soil. Protein separation was conducted at $\mathrm{pH} 4-7$ 
Table 1. Proteins indentified by LC-MS-MS/MS analyses

\begin{tabular}{|c|c|c|c|c|c|c|c|c|}
\hline $\begin{array}{l}\text { Spot } \\
\text { No. }\end{array}$ & Protein name & Function & Species & Protein ID & $\begin{array}{c}\mathrm{pI} \\
\text { experimental }\end{array}$ & $\begin{array}{l}\text { Mass } \\
(\mathrm{kDa})\end{array}$ & $\begin{array}{c}\mathrm{pI} \\
\text { theoretical }\end{array}$ & $\begin{array}{c}\text { Mascot } \\
\text { Score }\end{array}$ \\
\hline 1 & Isoflavone reductase related protein & Defense & Pyrus communis & Gi:3243234 & 6.65 & 36.1 & 6.02 & 98 \\
\hline 2 & F1 ATPase & $\begin{array}{l}\text { Provides energy for } \\
\text { the cell }\end{array}$ & Pisum sativum & Gi:2116558 & 5.63 & 60.3 & 6.63 & 119 \\
\hline 3 & L-ascorbate peroxidase, cytosolic & Detoxification & Pisum sativum & Gi:1351963 & 6.28 & 28.6 & 5.52 & 92 \\
\hline 4 & $\begin{array}{l}\text { Chain A, crystal structure of } \\
\text { recombinant ascorbate peroxidase }\end{array}$ & Detoxification & Pisum sativum & Gi:1420981 & 6.28 & 27.3 & 5.52 & 93 \\
\hline 5 & Heat shock protein hsp 70 & Defense & Pisum sativum & Gi:445605 & 5.0 & 75.8 & 5.22 & 124 \\
\hline 6 & Enolase & $\begin{array}{l}\text { Carbohydrate } \\
\text { and energy } \\
\text { metabolism }\end{array}$ & Ricinus communis & Gi:255575355 & 5.90 & 57.8 & 5.62 & 224 \\
\hline 7 & $\begin{array}{l}\text { Chalcone--flavanone isomerase 1B-2- } \\
\text { like }\end{array}$ & $\begin{array}{c}\text { Adaptation and } \\
\text { protection }\end{array}$ & Cicer arietinum & Gi:502121457 & 6.0 & 26.4 & 5.55 & 96 \\
\hline 8 & Ethylene-responsive enolase & $\begin{array}{c}\text { Energy } \\
\text { metabolism, defense }\end{array}$ & $\begin{array}{c}\text { Solanum } \\
\text { lycopersicum }\end{array}$ & Gi:5669648 & 6.81 & 57.1 & 4.75 & 152 \\
\hline 9 & $\begin{array}{l}\text { S-adenosylmethionine synthethase, } \\
\text { partial }\end{array}$ & & Pisum sativum & Gi:609557 & 6.02 & 43.9 & 6.60 & 98 \\
\hline 10 & $\begin{array}{l}\text { ATP-syntase subunit beta, } \\
\text { mitochondrial }\end{array}$ & $\begin{array}{l}\text { Carbohydrate } \\
\text { and energy } \\
\text { metabolism }\end{array}$ & Glycine $\max$ & Gi:356536246 & 5.63 & 63.2 & 5.80 & 221 \\
\hline 11 & V-type proton ATPase subunit E & $\begin{array}{c}\text { Proton pomp, } \\
\text { adaptation and } \\
\text { protection }\end{array}$ & Gossypium hirsutum & Gi:3334405 & 6.02 & 28.1 & 6.50 & 66 \\
\hline 12 & $\begin{array}{l}\text { Malate dehydrogenase, } \\
\text { mitochondrial-like }\end{array}$ & $\begin{array}{c}\text { Energy } \\
\text { metabolism }\end{array}$ & Cicer arietinum & Gi:502155344 & 6.47 & 36.6 & 8.71 & 102 \\
\hline
\end{tabular}




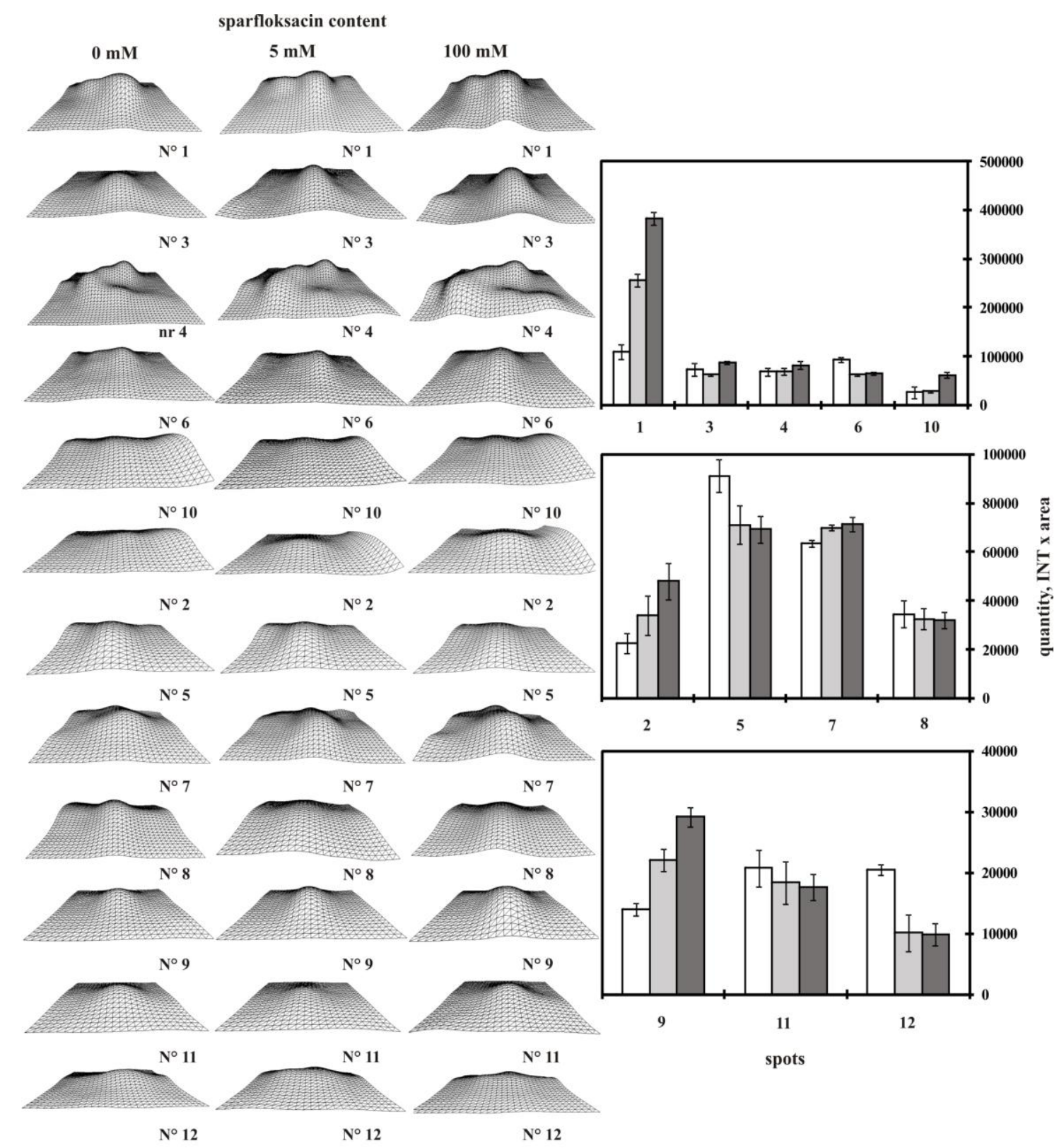

Figure 4. Intensity of destaining (PDQuest, BioRad) of proteins from control seedlings ( $\square$ ) and

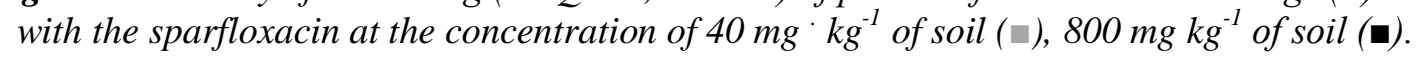

Number of spots $1,2 \ldots .10$ - see in Table 1

\section{Discussion}

Excellent antibacterial properties of some pharmaceuticals resulted in their wide use in human and veterinary medicine and agriculture (Sarmah et al., 2006). Floroquinolons belong to the most commonly applied drugs, worldwide (Khetan and Collins, 2007). Intensive use of pharmaceuticals results in their increased presence in the environment (Gartiser et al., 2007). Antibiotics are weakly metabolised, so they are passed to the environment unchanged or as active metabolites (Allen et al., 2011). Plants readily take up pharmaceuticals from soil which results in morphological and biochemical anomalies (Liu 
et al., 2013). Plant sensitivity to pharmaceuticals may be exploited for assessment of rate environmental degradation of drugs (Pomati et al., 2004; Adomas et al., 2013).

A biotest, based on seed germination and seedlings elongation measurements, may be applied for determination of the degree of environmental contamination by xenobiotics (Piotrowicz-Cieślak et al., 2010). Increasing soil concentrations of SPX lead to inhibition of root and stem growth in garden pea (Fig. 1A). The highest tested SPX concentration (800 $\mathrm{mg} \mathrm{kg}{ }^{-1}$ ) decreased root and stem length by $54 \%$ and $46 \%$, respectively, compared to control seedlings. The root and stem length correlated with seedling dry and fresh weight. Fresh weight of roots and stems decreased due to soil contamination with SPX, while dry weight slightly increased (Fig. 1B).

Adomas et al. (2013) have described inhibitory effect of enrofloxacin on elongation of narrow leaved lupin seedlings. Root and stem growth inhibition was also documented for legume seedlings (lupin, pea and lentil) grown in soil contaminated with diclophenac (Ziółkowska et al., 2014). The SPX concentrations used in our experiments were higher (5 and 8-fold higher), compared to those used in previous studies, $12 \mathrm{mM}$ diclophenac (Ziółkowska et al., 2014) and $20 \mathrm{mM}$ sulfamethazine (Piotrowicz-Cieślak et al., 2010), respectively. SPX (at $800 \mathrm{mg} \mathrm{kg}^{-1}$ i.e. $100 \mathrm{mM}$ ) inhibited root growth by $54 \%$ and stem growth by $46 \%$ (Fig. 1A) which suggests that it is less toxic than diclophenac (inhibiting pea root growth by $83 \%$ and stem growth by $91 \%$ at $12 \mathrm{mM}$ concentration (Ziółkowska et al., 2014)). It is also less toxic than sulfamethazine (Piotrowicz-Cieślak et al., 2010).

Soluble carbohydrate contents in seedlings correlate with their growth (Ziółkowska et al., 2014; Frias et al., 1996). During germination of legume seeds their monosacharide, disaccharide and cyclitol contents increase (Goyoaga et al., 2011). In our experiments a positive correlation was found between seedling length and sugar contents. The following sugars were identified in roots of pea plants, both control or affected by SPX: fructose, glucose, sucrose and myo-inositol (Fig. 2). It was noted that with increasing sparfloxacin concentration in soil the content of sugars in roots (as organs directly affected by the xenbiotic) decreased. Decreased quantities of soluble sugars were also found in seedlings grown in soil contaminated with diclophenac. Also with this pharmaceutical, like in our current experiments, a negative correlation was observed between plant soluble carbohydrate contents and drug concentrations in soil. We believe, therefore, that sucrose metabolism is a good predictor of seedling growth in contaminated soils, although it does not indicate the level of contamination. Therefore, determinations of soluble carbohydrates in plants may not be used for assessment of the level of soil contamination with antibiotics.

Adverse environmental conditions cause oxidative stress in plants by enhancing production of reactive oxygen species (ROS). To protect tissues and subcellular systems from toxic actions of ROS plants activate adaptive (detoxification) reactions (Caverzan et al., 2012). Ascorbate, glutathione and guaiacol peroxidases participate in ROS scavenging (Faltin et al., 2010). Peroxidases (POX), in spite of their low substrate specificity, are considered good biomarkers of stress in plants. POX contribute to defence/protective reactions but also participate in developmental processes, auxin and ethylene metabolim, cell wall lignification and suberinization (Lepeduš et al., 2004).

The experiments reported here show that with increasing SPX concentrations peroxidase activity in roots of pea seedlings increased (Fig. 1C). The results confirm pharmaceutical inducing effect on oxidative stress in plants (Caverzan et al., 2012). Even the lowest concentrations of SPX $\left(0.08,0.4\right.$ and $\left.0.8 \mathrm{mg} \mathrm{kg}^{-1}\right)$ resulted in significant increase of POX activity in seedling roots (by 22, 29 and 33\%, respectively). Sharp increase of enzyme activity under the influence of such low antibiotic quantities suggests imminent activation 
of mechanisms protecting plants from ROS. In roots of pea seedlings subjected to the highest SPX concentration ( $800 \mathrm{mg} \mathrm{kg}^{-1}$ of soil) peroxidase activity increased by as much as $55 \%$. Plant adaptive reactions to oxidative stress may vary depending on plant species and chemical properties of the stress inducing substance. Plants may differ in their capability to take up various antibiotics (Pomati et al., 2004). Zabalza et al. (2007) observed decreased activity of guaiacol peroxidase in pea roots resulting from herbicide (imazetapir) action. In addition to antibiotics and herbicides, many other stressors may cause adaptive reactions in plants (Caverzan et al., 2012). Activity of guaiacol peroxidase in roots of common bean (Phaseolus vulgaris) was stimulated by salt stress (Jebara et al., 2005).

Legume plants are a rich source of protein for human and animal nutrition. Pea and bean seeds abound in protein, which makes up $20 \%$ of their dry mass. Plant tissues are considered a rather challenging material for protein purification (Pavoković et al., 2012). Using the two-dimensional maps of pea root proteins differences in protein profiles of control plants (Fig. 3A) and plants treated with SPX (40 and $800 \mathrm{mM}$, Fig. 3 B and C) were shown. Much more spots (217) were visualised on the map of proteins from roots responding to the highest SPX concentration $\left(800 \mathrm{mg} \mathrm{kg}^{-1}\right)$ than from control roots (176 spots). More spots were also visible on protein map obtained for pea subjected to SPX at the level of $\mathrm{mg} \mathrm{kg}^{-1}$. Increased protein levels result from plant stress response. In 2Delectrophoresis 92 proteins were detected that were common to all samples (from control and SPX-treated plants). Twelve proteins were selected for identification by mass spectrometry. Proteins involved in plant adaptation and protection from detrimental effects of environment were found. The most intense spots on protein maps of roots affected by SPX (40 and $800 \mathrm{mg} \mathrm{kg}$ ) were identified as isoflavone reductase related protein. Isoflavones are mainly identified in legumes. They participate in plant defence against phytopathogens, acting as phytoalexins (Shimada et al., 2000). A key role in isoflavonoid biosynthesis is played by isoflavone reductase (IFR). IFR catalyzes $\mathrm{NADP}^{+}$reduction in biosynthesis of plant protective metabolites (derivatives of phenylpropanoids) (Franca et al. 2001). Isoflavone reductase, like L-ascorbate peroxidase is involved in detoxication of reactive oxygen species (ROS). Chalcone synthase is another key enzyme in isoflavonoid and flavonoid biosynthesis (Dao et al., 2011). Chalcone-flavanone isomerise, catalysing an early step in flavonoid biosynthesis, was also detected on 2D maps of plant proteins. Chalcone-flavanone isomerase is also involved in plant adaptation and protection from environmental stresses (Shoeva et al., 2014). Induction of this enzyme in roots growing in the presence of SPX (40 and $800 \mathrm{mg} \mathrm{kg}^{-1}$ ) points to adverse action of this antibiotic on plants. According to the literature changes in content of chalcone synthase and chalcone isomerase in Arabidopsis mutants result in plant supersensitivity to UV radiation (WinkelShirley, 2002). Adaptive role may also be played in plants by an identified Sadenosylmethionine synthetase and subunit E of V-type proton ATPase. Yet another group of identified proteins are those involved in bioenergetic metabolism and suppressed by increasing concentrations of antibiotic.

Differences in abundancy of proteins identified on proteomic maps of control roots and those subjected to SPX (40 and $800 \mathrm{mg} \mathrm{kg}^{-1}$ ) indicate a plant protection response activation. Abiotic stresses in plants result in gene activation and modification of metabolite and protein pools. Some of these proteins may be essential for conferring a certain level of plant protection from stressors (Bhatnagar-Mathur et al., 2008).

Acknowledgments. This project was supported by project National Science Centre Poland, UMO011/01/B/NZ9/02646. 


\section{REFERENCES}

[1] Adomas, B., Antczak-Marecka, J., Nałecz-Jawecki, G., Piotrowicz-Cieślak, A.I. (2013): Phytotoxicity of enrofloxacin soil pollutant to narrow-leaved lupin plant. - Polish Journal of Environmental Studies (22)1: 71-76.

[2] Allen, H. K., Looft, T., Bayles, D.O., Humphrey, S., Levine, U.Y., Alt, D., Stanton, T.B. (2011): Antibiotics in feed induce prophages in swine fecal microbiomes. - MBio 2(6): $1-9$.

[3] Andreu, V., Vazquez-Roig, P., Blasco, C., Picó, Y. (2009): Determination of tetracycline residues in soil by pressurized liquid extraction and liquid chromatography tandem mass spectrometry. - Analytical and Bioanalytical Chemistry 394(5): 1329-1339.

[4] Awad, Y.M., Kim, S.C., M.Abd El-Azeem, S.A., Kim, K.H., Kim K.R., Kim, K. Jeon, C., Lee, S.S., Ok, Y.S. (2014): Veterinary antibiotics contamination in water, sediment, and soil near a swine manure composting facility. - Environmental Earth Sciences 71: 1433-1440.

[5] Bhatnagar-Mathur, P., Vadez, V., Sharma, K.K. (2008): Transgenic approaches for abiotic stress tolerance in plants: retrospect and prospects. - Plant Cell Reports 27(3): 411-424.

[6] Caverzan, A., Passaia, G., Rosa, S.B., Ribeiro, C.W., Lazzarotto, F., Margis-Pinheiro, M. (2012): Plant responses to stresses: Role of ascorbate peroxidase in the antioxidant protection. - Genetics and Molecular Biology 35(4): 1011-1019.

[7] Chen, Y., Zhang, H., Luo Y., Song, J. (2012): Occurrence and dissipation of veterinary antibiotics in two typical swine wastewater treatment systems in east China. Environmental Monitoring and Assessment 184(4): 2205-2217.

[8] Dao, T.T.H., Linthorst, H.J.M., Verpoorte, R. (2011): Chalcone synthase and its functions in plant resistance. - Phytochemistry Reviews 10(3): 397-412.

[9] Faltin, Z., Holland, D., Velcheva, M., Tsapovetsky, M., Roeckel-Drevet, P., Handa, A.K., Abu-Abied, M., Friedman-Einat, M., Eshdat, Y., Perl, A. (2010): Glutathione peroxidase regulation of reactive oxygen species level is crucial for in vitro plant differentiation. Plant and Cell Physiology 51(7): 1151-1162.

[10] França, S.C., Roberto, P.G., Marins, M.A., Puga, R.D., Rodrigues, A., Pereira, J.O. (2001): Biosynthesis of secondary metabolites in sugarcane. - Genetics and Molecular Biology 24(1-4): 243-250.

[11] Frias, J., Vidal-Valverde, C., Kozlowska, H., Górecki, R., Honke, J., Hedley, C.L. (1996): Evolution of soluble carbohydrates during the development of pea, faba bean and lupin seeds. - Zeitschrift fur Lebensmittel-Untersuchung und Forschung 203(1): 27-32.

[12] Gartiser, S., Urich, E., Alexy, R., Kümmerer, K. (2007): Ultimate biodegradation and elimination of antibiotics in inherent tests. - Chemosphere 67(3): 604-613.

[13] Goyoaga, C., Burbano, C., Cuadrado, C., Romero, C., Guillamón, E., Varela, A., Pedrosa, M.M., Muzquiz, M. (2011): Content and distribution of protein, sugars and inositol phosphates during the germination and seedling growth of two cultivars of Vicia faba. Journal of Food Composition and Analysis 24(3): 391-397.

[14] ISTA International Rules for Seed Testing Edition. (2011): The International Seed Testing Association 1-56. - Basserdorf, Zurich

[15] Jebara, S., Jebara, M., Limam, F., Aouani, M.E. (2005): Changes in ascorbate peroxidase, catalase, guaiacol peroxidase and superoxide dismutase activities in common bean (Phaseolus vulgaris) nodules under salt stress. - Journal of Plant Physiology 162(8): 929-936.

[16] Jia, A., Wan, Y., Xiao, Y., Hu, J. (2012): Occurrence and fate of quinolone and fluoroquinolone antibiotics in a municipal sewage treatment plant. - Water Research 46: 387-394. 
[17] Karci, A., Balcioglu, I.A. (2009): Investigation of the tetracycline, sulfonamide and fluoroquinolone antimicrobial compounds in animal manure and agricultural soils of Turkey. - Science of the Total Environment 407: 4652-4664.

[18] Khetan, S.K., Collins, T.J. (2007): Human pharmaceuticals in the aquatic environment: A challenge to green chemistry. - Chemical Reviews 107(6): 2319-2364.

[19] Lepeduš, H., Cesar, V., Krsnik-Rasol, M. (2004): Guaiacol peroxidases in carrot (Daucus carota L.) root. - Food Technology and Biotechnology 42(1): 33-36.

[20] Lillenberg, M., Litvin, S.V., Nei, K., Roasto, M., Sepp, K. (2010): Enrofloxacin and ciprofloxacin uptake by plants from soil. - Agronomy Research 8(1): 807-814.

[21] Liu, F., Ying, G., Tao, R., Zhao, J., Yang, J., Zhao, L. (2009): Effects of six selected antibiotics on plant growth and soil microbial and enzymatic activities. - Environmental Pollutio 157(5): 1636-1642.

[22] Liu, L., Liu, Y.H., Liu, C.X., Wang, Z., Dong J., Zhu, G.F., Huang, X. (2013): Potential effect and accumulation of veterinary antibiotics in Phragmites australis under hydroponic conditions. - Ecological Engineering 53: 138-143.

[23] Lowry, O.H., Rosebrough, N.J., Farr, A.L., Randall, R.J. (1951): Protein measurement with the Folin phenol reagent. - Journal of Biological Chemistry 193(1): 265-275.

[24] Martínez-Carballo, E., González-Barreiro, C., Scharf, S., Gans, O. (2007): Environmental monitoring study of selected veterinary antibiotics in animal manure and soils in Austria. - Environmental Pollution 148(2): 570-579.

[25] Pailler, J., Krein, A., Pfister, L., Hoffmann, L., Guignard, C. (2009): Solid phase extraction coupled to liquid chromatography-tandem mass spectrometry analysis of sulfonamides, tetracyclines, analgesics and hormones in surface water and wastewater in Luxembourg. - Science of The Total Environment 407(16): 4736-4743.

[26] Pavoković, D., Križnik, B., Krsnik-Rasol, M. (2012): Evaluation of protein extraction methods for proteomic analysis of non-model recalcitrant plant tissues. - Croatica Chemica Acta 85(2): 177-184.

[27] Pinheiro, A., Albano, R.M., Alves, T.C., Kaufmann, V., Silva, M.R. (2013): Veterinary antibiotics and hormones in water from application of pig slurry to soil. - Agricultural Water Management 129: 1-8.

[28] Piotrowicz-Cieślak, A.I., Adomas, B., Nałecz-Jawecki, G., Michalczyk, D.J. (2010): Phytotoxicity of sulfamethazine soil pollutant to six legume plant species. - Journal of Toxicology and Environmental Health Part A, 73(17-18): 1220-1229.

[29] Piotrowicz-Cieślak, A.I., Michalczyk, D.J., Adomas, B., Górecki, R.J. (2007): Different effects of soil drought on soluble carbohydrates of developing Lupinus pilosus and Lupinus luteus embryos. - Acta Societatis Botanicorum Poloniae 76(2): 119-125.

[30] Pomati, F., Netting, A.G., Calamari, D., Neilan, B.A. (2004): Effects of erythromycin, tetracycline and ibuprofen on the growth of Synechocystis sp. and Lemna minor. - Aqua Toxicology 67(4): 387-396.

[31] Sarmah, A.K., Meyer, M.T., Boxall, A.B.A. (2006): A global perspective on the use, sales, exposure pathways, occurrence, fate and effects of veterinary antibiotics (VAs) in the environment. - Chemosphere 65(5): 725-759.

[32] Seo, Y.H., Cho, B.O., Kang, A.S., Jeong, B.C., Jung, Y.S. (2010): Antibiotic uptake by plants from soil applied with antibiotic - treated animal manure. - Korean Journal of Soil Science and Fertilizer 43(4): 466-470.

[33] Shimada, N., Akashi, T., Aoki, T., Ayabe, S.I. (2000): Induction of isoflavonoid pathway in the model legume Lotus japonicus: Molecular characterization of enzymes involved in phytoalexin biosynthesis. - Plant Science 160(1): 37-47.

[34] Shoeva, O.Y., Khlestkina, E.K., Berges, H., Salina, E.A. (2014): The homoeologous genes encoding chalcone-flavanone isomerase in Triticum aestivum L. Structural characterization and expression in different parts of wheat plant. - Gene 538, (2): 334341. 
[35] Sukul, P., Spiteller, M. (2007): Fluoroquinolone antibiotics in the environment. Reviews of Environmental Contamination and Toxicology 191: 131-162.

[36] Wammer, K.H., Korte, A.R., Lundeen, R.A., Sundberg, J.E., McNeill, K., Arnold, W.A. (2013): Direct photochemistry of three fluoroquinolone antibacterials: norfloxacin, ofloxacin, and enrofloxacin. - Water Research 47(1): 439-448.

[37] Winkel-Shirley, B. (2002): Biosynthesis of flavonoids and effects of stress. - Plant Biology 5: 218-223.

[38] Zabalza, A., Gaston, S., Sandalio, L.M., Ríob, L.A., Royuela, M. (2007): Oxidative stress is not related to the mode of action of herbicides that inhibit acetolactate synthase. Environmental Experimental Botany 59(2): 150-159.

[39] Zhang, H.R., Zhang, M.H., Gu, G.P. (2008): Residues of tetracyclines in livestock and poultry manures and agricultural soils from north Zhejiang Province. - Journal of Ecology Rural Environment 24(3): 69-73.

[40] Ziółkowska, A., Piotrowicz-Cieślak, A.I., Rydzyński, D., Adomas, B., Nałecz-Jawecki, G. (2014): Biomarkers of leguminous plant viability in response to soil contamination with diclofenac. - Polish Journal of Environmental Studies 23(1): 263-269.

[41] Ziółkowska, A., Piotrowicz-Cieślak, A.I., Margas, M., Adomas, B., Nałęcz-Jawecki, G. (2015): Accumulation of tetracycline, oxytetracycline and chlortetracycline in pea (Pisum sativum L.). - Fresenius Environmental Bulletin 24(4A): 1386-1391. 